\title{
Comparative Study Of Different Solar Cooking Apparatus
}

\author{
Susan John \\ Department of Physics \\ SFS College, NAGPUR 06 \\ Email i.d.:susanjohnphy@gmail.com
}

\begin{abstract}
A study was performed to compare the existing solar cooking apparatus available in the market. Though many models are available but still solar cookers are not being used by common people here in India. The solar cooker should show superior performance in a wide range of heating applications such as cooking, roasting, baking and frying.

The solar cooker should have elegant design and it should have other qualities such as easy to transport, durability, mobility and above all easy to operate and at same time efficiency should also be high. In this paper attempt has been made to provide comprehensive view on the various disadvantages of different type of solar cooking apparatus.
\end{abstract}

Keywords: Box cookers, flat reflector, solar panel cooker, collapsible reflectors

\section{INTRODUCTION}

Conventional cookers which uses traditional fuels such as woods, charcoal dried cow dung, LPG gas, most of which produces health -damaging pollutants, are commonly used in India but it has a lots of disadvantages as it creates lots of air pollution which can be overcome by the use of solar cookers which uses solar energy for its operation and at same time solar energy does not create any pollution.

But these solar powered solar cookers have lots of disadvantages as it is very difficult to operate at the same time it is inefficient. This disadvantages leads to less widespread use of solar cooker in an average Indian house. There are several types of solar cookers available in the market. But each one has its own shortcomings. Let discuss each models.

\section{DIFFERENT TYPES OF SOLAR COOKING MODELS: Different types of solar cooking models are available which are discussed below:}

A) Box cookers: Box cookers as the name indicates are box shaped. It is insulated from all sides except at the top where glass panel is placed for green house effect. But because of this glass panel most of the heat escapes from the box cooker which ultimately affects its efficiency. Moreover it is bulky, slow to cook and difficult to handle.

B) Solar cooker with a parabolic reflector: It is also known as concentrating cookers or line focus. It uses double-curved concave reflector which converge the sun-rays to a relatively smaller area. It has serious disadvantages such as it is very large, very difficult to operate, needs eye shielding as it reflects light to the eyes of one who operates its and also heat escapes out from the cooker easily. This type of cooker make use of direct rays of sun hence the image area where direct sun rays are concentrated moves too quickly so one needs to adjust the parabola frequently in order to obtain desired heat level for cooking. As described in U.S patent no. 4002,499 [1].There is serious need to capture all the heat energy which falls on it and this can be done by means of increasing the thermal insulations.

As described in U.S. patent no 4083357 [2] it can be easily adjusted with the orientation of sun, it needs less skill to focus. It makes use of parabolic cylinder reflectors. It also provides with a sliding friction lock so that the wind cannot change the image position of cooker. It is provided with oven in the form of cylindrical shaped cooking container which is transparent plastic; it transmits most of sun rays through the bottom so that all the food kept in the cooker can be cooked properly in all direction. The top of the oven is insulated by a cover lined inside which make use of reflective material to trap all sun rays.

C) Solar cooker with a flat reflector: As described in U.S. patent no.4099516 [3] makes use of flat plates which is coated with black, as black absorbs most of the energy which falls upon it. These plates are provided with channels for circulating a liquid (preferably water) to be warmed. The advantage of this cooker is that it is economical but at the same time it loses its most of sun rays which falls on it because of its geometry i.e. flat.

As explained in U.S. patent no.4099516 [4] make use of addition of series of spaced apart flat planes arranged in a plane above the flat plate. These arrangements increase the trap of heat energy between the spaced flat plates and also reduce the amount of heat lost as it decreases the outward flow of radiation from the flat plate.

As explained in another U.S. patent no. 4134392 [5] collects the solar energy makes use of collector 
International Journal of Research in Advent Technology, Vol.7, No.4, April 2019

E-ISSN: 2321-9637

Available online at www.ijrat.org

which is long, elongate, trough-shaped body with an inner reflective surface, without making use of solar energy tracking system. D) Solar panel cooker: These types of cookers make uses of large panels. Again these cookers are very large in size, and it takes a longer period of time to generate low heat levels. It also lacks any technology to trap heat energy.

E) Solar cooker with collapsible reflectors:

In U.S. patent no. 806134 [6] makes use of collapsible reflectors capable of being folded when not in use. According to this patent it makes use of several blades which is mounted on common axis, and can be opened like a fan. [U.S patent no. 2586583][7]

\section{CONCLUSIONS}

The present paper gives idea of solar cooker with different designs available. But all of these cookers face one or other disadvantages as described in above sections. While constructing the solar cooker one should keep in mind that it should not only economical but at the same time the collection area of solar rays should be increased without increasing the size of apparatus for longer time by means of using stray solar rays and diffused light along with the direct rays. By making use of stray solar rays and diffused light the efficiency of solar rays can be increased which is one of biggest challenge. Till the solar cookers available in the marked makes use of direct rays because of which it needs frequent adjustment of the apparatus to obtain maximum rays and makes use of many supporting equipments which ultimately increase the cost.

\section{REFERENCE}

[1] https://books.google.co.in/books?id=FAORC4pP p9IC\&pg=PA279\&lpg=PA279\&dq=PARABOLI C+REFLECTOR+4002+499\&source=bl\&ots=Io LZTyPbgX\&sig=ACfU3U1SMjHmO5MpokBP YqL_UebAIg94A\&hl=en\&sa=X\&ved=2ahUKE wibhJCQsNHhAhVw4HMBHXSfBR8Q6AEwD

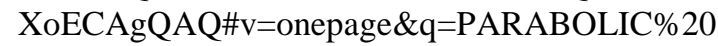
REFLECTOR\%204002\%20499\&f=fals
[2] http://patft.uspto.gov/netacgi/nphParser?Sect $2=$ PTO $1 \&$ Sect $2=$ HITOFF $\& \mathrm{p}=1 \& \mathrm{u}=$ $\% 2$ Fnetahtml\%2FPTO\%2Fsearchbool.html\&r=1\&f=G\&l=50\&d=PALL\&RefSrch= yes\&Query=PN\%2F4083357

[3] http://patft.uspto.gov/netacgi/nphParser?Sect $2=$ PTO $1 \&$ Sect $2=$ HITOFF $\& \mathrm{p}=1 \& \mathrm{u}=$ $\% 2$ Fnetahtml\%2FPTO\%2Fsearchbool.html\&r=1\&f=G\&l=50\&d=PALL\&RefSrch= yes\&Query=PN\%2F3929122

[4] http://patft.uspto.gov/netacgi/nphParser?Sect $2=$ PTO $1 \&$ Sect $2=$ HITOFF $\& \mathrm{p}=1 \& \mathrm{u}=$ $\% 2$ Fnetahtml\%2FPTO\%2Fsearchbool.html\&r=1\&f=G\&l=50\&d=PALL\&RefSrch= yes\&Query=PN\%2F3929122

[5] http://patft.uspto.gov/netacgi/nphParser?Sect $2=$ PTO $1 \&$ Sect $2=$ HITOFF $\& \mathrm{p}=1 \& \mathrm{u}=$ $\% 2$ Fnetahtml\%2FPTO\%2Fsearchbool.html\&r=1\&f=G\&l=50\&d=PALL\&RefSrch= yes\&Query=PN\%2F4134392

[6] https://pdfpiw.uspto.gov/.piw?PageNum=0\&doci $\mathrm{d}=02806134 \& \mathrm{IDKey}=\mathrm{A} 6415 \mathrm{~A} 586 \mathrm{CE} 1 \% 0 \mathrm{D} \% 0 \mathrm{~A}$ \&HomeUrl=http $\% 3 \mathrm{~A} \% 2 \mathrm{~F} \% 2 \mathrm{Fpatft}$.uspto.gov $\% 2$ Fnetacgi\%2Fnph-

Parser\%3FSect2\%3DPTO1\%2526Sect2\%3DHIT OFF\%2526p\%3D1\%2526u\%3D\%25252Fnetaht $\mathrm{ml} \% 25252 \mathrm{FPTO} \% 25252 \mathrm{Fsearch}-$ bool.html\%2526r\%3D1\%2526f\%3DG\%25261\%3 D50\%2526d\%3DPALL\%2526S1\%3D2806134.P N.\%2526OS\%3DPN\%2F2806134\%2526RS\%3D $\mathrm{PN} \% 2 \mathrm{~F} 2$

[7] https://pdfpiw.uspto.gov/.piw?PageNum=0\&doci $\mathrm{d}=02586583 \&$ IDKey $=21 \mathrm{D} 6 \mathrm{~B} 01 \mathrm{E} 3 \mathrm{FBB} \% 0 \mathrm{D} \% 0 \mathrm{~A}$ \&HomeUrl=http $\% 3 \mathrm{~A} \% 2 \mathrm{~F} \% 2 \mathrm{Fpatft}$. uspto.gov $\% 2$ Fnetacgi\%2Fnph-

Parser\%3FSect2\%3DPTO1\%2526Sect2\%3DHIT OFF\%2526p\%3D1\%2526u\%3D\%25252Fnetaht ml\%25252FPTO\%25252Fsearchbool.html\%2526r\%3D1\%2526f\%3DG\%25261\%3 D50\%2526d\%3DPALL\%2526S1\%3D2586583.P N.\%2526OS\%3DPN\%2F2586583\%2526RS\%3D PN\%2F2586583 